\title{
LOCAL NONPROFIT WELFARE PROVISION: THE UNITED STATES AND RUSSIA
}

\section{Wathen Maria V.}

Ph.D. candidate, Joint Program in Sociology \& Social Work, University of Michigan. Address: Department of Sociology, University of Michigan, Ann Arbor, MI 48109 USA.

E-mail: mwathen@umich.edu

\section{Allard Scott W.}

$\mathrm{PhD}$ in Political Science, Professor of Public Affairs, University of Washington. Address: Evans School of Public Affairs, University of Washington, Seattle, WA 98195-3055, USA. E-mail: sallard@uw.edu

\begin{abstract}
Provision of antipoverty and other social services by nonstate organizations is growing in importance in both the United States and the Russian Federation. The history of such provision in the United States may offer insights for the emerging system of nonstate provision in Russia. To illuminate these points, we provide historical overviews of both contexts and then we examine data from two surveys of social service organizations in the United States: the Multi-City Survey of Social Service Providers and the Rural Survey of Social Service Providers.

We find that nonstate actors strengthen social capital in poor neighborhoods and often link poor persons to public agencies. Nonstate actors strengthen other local institutions through programmatic partnerships and collaboration. However, financing arrangements of nonstate welfare provision may favor efficiency over concerns about equity, sustainability, and predictability. In addition, the primacy of nonstate provision leads to a welfare state that is more varied geographically than might be anticipated otherwise. Such variability appears to disadvantage highpoverty and predominately minority communities the most. Finally, politically, nonstate welfare provision may occur with little public discussion, debate, or reflection as it evolves over time. These findings invoke important questions for Russian policy-makers as they seek to develop an equitable and efficient means of providing assistance to their population.
\end{abstract}

Keywords: welfare policy U.S.-Russia; nonstate organization; nonprofit; NGO; noncommercial organization; government funding.

$\mathrm{T}$ he provision of antipoverty assistance by nonstate organizations is growing in importance in both the United States and the Russian Federation. In the United States, nonstate organizations - typically charitable nonprofits - have come to play a prominent role in the delivery of governmental antipoverty programs since the mid-1960s. Today, nonstate organizations in the United States deliver roughly $\$ 100$ billion dollars in social service programs - the vast majority funded by government sources - to support work activity, address barriers to self-sufficiency, and provide for basic material needs. Indeed, nonstate provi- 
sion of publicly funded safety net assistance has become a routinized part of the American welfare state (Allard, 2009; Smith, 2012).

In the Russian context, nonstate social service provision is slowly emerging. The number of nonstate organizations involved in the delivery of social services has increased in the years since the breakup of the Soviet Union in 1991. Russian national, regional, and local governments have increasingly provided grants and in-kind assistance (e.g., subsidized office space) to nonstate social service organizations. Despite these trends, nonstate welfare provision is still nascent and composes only a small share of services available (Benevolenski, 2014; Cook, 2007b).

In light of these developments in both nations, we argue that those concerned with nonstate delivery of safety-net assistance in Russia (or other highly centralized welfare states) may find insight from several features of more mature nonstate social service provision in the U.S. case. Below, we provide a brief historical overview of nonstate provision in each system. To cast insight into the institutional outcomes more likely to occur when nonstate actors play a primary role in welfare provision, we examine data from two surveys of social service organizations: the Multi-City Survey of Social Service Providers (MSSSP) in metropolitan Chicago, Los Angeles, and Washington, DC; and the Rural Survey of Social Service Providers (RSSSP) data from four rural regions (southeastern Kentucky, south-central Georgia, southeastern New Mexico, and the border counties of Oregon-California). Telephone interviews were completed with executives from 1,287 nonstate organizations that primarily provide employmentrelated services (e.g., job search, adult education), temporary emergency food or cash assistance, and out-patient substance abuse and/or mental health treatment. Each telephone survey gathered detailed information on location, services provided, clients served, funding, and organizational characteristics. ${ }^{1}$ With response rates that exceed 60 percent, these surveys are the most comprehensive and geographically sensitive data about nonstate welfare provision currently available and provide an accurate snapshot of the nonstate sector within each site (Allard 2009). ${ }^{2}$

The insights emerging from the data and U.S. history reveal some benefits and drawbacks that the Russian state may consider as it creates a stronger system. First, the capacity of the nonstate sector to deliver antipoverty programs has not emerged overnight in the United States; instead, it has been cultivated over several decades by persistent increases in government funding and expansion of local nonprofit organizational networks. Second, state-nonstate relationships surrounding social service provision have become more co-dependent in the United States over time. Direct public provision of social services is more costly than contracting with nonstate actors; thus, efficiency concerns have led government agencies to increasingly rely on the nonstate sector for service capacity. At the same time, many nonstate providers have become highly dependent on public funding to maintain operations. Finally, nonstate service provision in the United States reflects local preferences about how to provide assistance and whom to serve. Rather than channeling program resources to the neighborhoods and communities where they are most needed, therefore, the Ameri- 
can case strongly suggests that nonstate welfare provision can result in unequal provision of services that systematically disadvantages society's most vulnerable communities.

\section{Contemporary Nonstate Welfare Provision in Russia}

To understand how findings regarding nonstate social service provision in the United States can apply to Russia, it is important to first understand the context surrounding nonstate welfare provision in Russia. Historically, the Soviet welfare system, from which the Russian welfare system descended, was centrally planned, but implemented primarily through places of employment (Zimakova, 1993; Manning \& Shaw, 1998). The Soviet welfare state funded state-owned enterprises to provide childcare or early childhood education, healthcare, housing, nursing homes, and after-school activities. Many government cash benefits were delivered through employers, including retirement pensions, stipends for post-secondary students, and cash payments to new mothers (Balachova, Bonner \& Levy, 2008; Zimakova, 1993). At times, inefficiencies emerged due to duplication between state services provided through firms and those delivered by local government (Manning \& Shaw, 1998). For example, a family might have been eligible for housing from both their workplace and the local administration. Central planning created additional inefficiencies and hindered the quality of services provided (Ellman, 1979). In reality, the social services and welfare benefits available varied both by region or republic and by employer (IarskaiaSmirnova \& Romanov, 2009). Despite these limitations, many argue that Soviet social policy was successful in providing a basic standard of living to almost every citizen (Cook, 2007b).

Prior to the collapse of the Soviet Union in the early 1990s, nonstate organizations played a negligible role in social service provision. Yet, nonstate organizations have been present throughout Russian history. In the late nineteenth and early twentieth centuries, Russians began forming charitable associations and promoting volunteer service as a means of addressing social problems (Lindenmeyr, 1990; Raeff, 1984). After 1917, however, this type of free association among citizens was curtailed by the Soviet regime and replaced by alternative associations managed by the party apparatus (Evans, 2006). These organizations included veterans groups, youth and hobby clubs, and associations for people with disabilities. Such organizations were active in providing some services at the local level, although they did not play an active role in policymaking and for the most part were social organizations.

The breakup of the Soviet Union in 1991 and transition to a territorially smaller Russian Federation was economically and socially tumultuous. Provision of social services became highly unpredictable, as the state could not afford to maintain program expenditures and newly independent enterprises cut benefits to reduce operating costs (Field \& Twigg, 2000). During the turbulent decade that followed the collapse of the Soviet Union, international actors influenced the provision of social welfare. International economic development organizations such as the World Bank and the International Monetary Fund (IMF) ad- 
vocated for neoliberal policies in Russia's transition to a market economy. These policies view social welfare provision, and the state or nonstate actors involved in such provision, as less central to goals of maximizing economic productivity. Structural adjustment programs linked to loan agreements imposed policies that affected the financing and operation of social welfare states in countries such as Russia (Baker \& Hinds, 2012; Deacon, Hulse \& Stubbs, 1997). Russia pursued a neoliberal path under President Boris Yeltsin in the 1990s, but bureaucratic stakeholders in the health, education, and pension systems blocked extreme cost-cutting measures and managed to preserve some state capacity for welfare provision (Cook, 2007a).

Recent years have brought some experiments with decentralization. For example, in 2005 the Russian government transferred responsibility for provision of child welfare and family support to regional and municipal levels of government, although federal grants help cover program costs (Ferge, 2001; Trygged, 2009). Regional and local governments have worked hard to address the needs of their constituents, with varying levels of resources and success. On the one hand, some layers of bureaucracy have been removed. On the other, the transition has varied across regions. Municipalities with larger budgets and stronger economies are better able to provide funding for such programs than smaller regions. At the same time, national commitments to other types of assistance were maintained, including healthcare, pensions, and payments to invalids. However, even these national systems reflect resource or wealth disparities between regions of the country, and the quality and accessibility of assistance varies (Titterton, 2006). For example, pensioners in Moscow receive substantial pension subsidies from the city government in addition to national pension amounts. Experiments with decentralization have thus resulted in varying levels of efficiency and provision of services across regions.

As the Russian state struggled to handle its social welfare responsibilities following the breakup of the Soviet Union, nonstate organizations attempted to fill the gaps in services (Petukhov, 2008; Salmenniemi, 2010). The 1990s were characterized by an explosive proliferation of nonstate organizations, with 60,000 nonstate organizations registering with the Russian government from 1993 to 2005 (U.S. Agency for International Development, 2005). Many of these nonstate organizations provided services to disadvantaged populations, including the disabled, street children, orphans, single-parent families, veterans, the elderly, and others. Organizations also focused on preventive services and public awareness. Collaboration between local and regional governments and nonstate actors increased in the 1990s due to limited public funds and the need to find more cost effective ways to provide needed services (Belokurova \& Vorob'ev, 2011). An influx of funding and consultants from foreign sources also aided the establishment of social welfare nonstate organizations across Russia. There is debate, however, about the impact of these efforts, whose interests were served by these international efforts to cultivate nonstate capacity, whether foreign influence stifled local initiative and collaboration, and whether contextualization of foreign programs and methods was lacking (Henderson, 2002; Richter, 2009). 
The new millennium brought changes to how the Russian state viewed nonstate organizations and these changes affected all types of such organizations. From 2003 to 2005, the color revolutions in Georgia, Ukraine, and Kyrgyzstan highlighted the potential for citizen protest organized through nonstate organizations. These organizations, particularly those receiving foreign support, were suddenly on the radar of the Kremlin (Cavanaugh, 2010; Cook \& Vinogradova, 2006). In 2005, Vladimir Putin created the Civic Chamber of the Russian Federation (sometimes translated Public Chamber) to act as a channel of communication between citizen organizations and the Duma. In 2006, legislation designed to regulate nonstate organizations was passed. Often called "the NGO law," the legislation increased government oversight of organizations through stricter registration and reporting requirements (Crotty, Hall \& Ljubownikow, 2014; Ka$\mathrm{mhi}, 2006)$. Although designed to provide the central government with greater oversight and control, the requirements often had negative impacts, particularly on smaller nonstate social service organizations. Cumbersome and frequent reporting requirements on activities, members, and funding created hours of work for organizations with few, if any, paid staff (Ljubownikow \& Crotty, 2014). In addition, organizations that received foreign funding were subject to more stringent oversight. The level of foreign funding dramatically declined, leaving fledgling organizations scrambling for survival (Iarskaia-Smirnova, 2011; Johnson \& Saarinen, 2011; Sperling, 2006).

To preclude social unrest and cover some of the funding gap, the government began allocating more funds to social welfare initiatives and encouraging regions to channel some of this money to nonstate organizations (Henderson, 2011; Salmenniemi, 2010). Currently, nonstate social service organizations can potentially receive funding from multiple levels of government -local, regional, and national. In 2012, the Civic Chamber administered competitive grants totaling two billion rubles (\$64 million) to nonstate service organizations (Public Chamber, 2012). However, these grants do not reach many nonstate organizations; in 2010 only an estimated 0.2 percent of registered organizations had been awarded Civic Chamber grants (Public Chamber, 2010). The Russian government passed another set of laws in 2012 regulating nonstate organizations, while also pledging greater financial support for nonstate social service organizations. The most publicized aspect of this law is a requirement that nonstate organizations register themselves as a "foreign agent" if they receive any funding from a foreign source (Law number 102766-6 July 2012).

In 2015, the scope of service, financial support, and roles of Russian nonstate social service organizations reflect the political and economic soil from which they grew. There are approximately 115,000 actively working Russian social welfare-oriented nonstate organizations (Benevolenski, 2014). The national, regional, and municipal branches of government are growing in their willingness to supply material support such as grants, office space with subsidized rent, or consultation and training (Alekseeva, 2010; Benevolenski, 2014). Nonstate organizations today provide services in a myriad of areas, from child and family welfare to addiction recovery to elder care to disability services. Although the government often partners with these organizations, the proportion of services 
provided by nonstate organizations remains under 10 percent. Relationships between the majority of nonstate social service organizations and the state are moving in the direction of greater collaboration, but also greater dependency on the Russian government. Despite the small number of nonstate social service organizations, government restrictions, and lack of resources to support programming, nonstate organizations participate in policy formation at the local level, where municipal and regional administrations often call for their expertise in policy decisions (Belokurova \& Vorobyev, 2011). Recent studies of nonstate social service organizations find that when organizations are dependent on state funding and are focused on noncontroversial social issues, they can have a greater influence on policy decisions in the local context (Beznosova \& Sundstrom, 2009; Johnson \& Saarinen, 2011; Ljubownikow, Crotty \& Rodgers, 2013; Froehlich, 2012).

While inherited patterns of organization-state collaboration are helpful to some degree, certain aspects of the Soviet bureaucratic legacy may continue to hinder nonstate organization development. Scholars cite the continued reliance on personal contacts and patronage (Henderson, 2011; Salmenniemi, 2010), vertical versus horizontal management styles (Johnson \& Saarinen, 2011; Ledeneva, 2006), and state restriction of the activity of organizations as key constraints on nonstate welfare provision. Others point specifically to the failure of foreign funders to take into account both local political environments and Russian norms and beliefs (Crotty, 2009; Sundstrom, 2006). In addition, Russian citizens remain uneducated about the role of nonstate organizations in society (Civic Chamber, 2013), wary of nonstate organizations (Evans, 2011; Henderson, 2011; HSE, 2011; Salmenniemi, Borodina, Borodin \& Rautio, 2009) and reluctant to join organizations (Petukhov, 2008; Rimskii, 2008). Livshin and Weitz found that though domestic donations are increasing, the majority of funding goes to state-run institutions such as orphanages instead of nonstate organizations (2006). Partly as a result of foreign funding patterns and partly from the mistrust of the public, nonstate organizations also are challenged to build longterm organizational capacity from funding that is limited to short-term projects. This capacity puzzle for nonstate organizations began with ties to international donors, yet it continues with the grant cycles of the government today (Jakobson \& Sanovich, 2010; Johnson \& Saarinen, 2011).

In summary, while a myriad of challenges continue to arise in nonstate organization provision of social services and in nonstate organization-state collaboration in Russia, there are a number of positive signs indicating the health and growth of the sector. Jakobson and Sanovich (2010) argue that Russian nonstate organizations are diverse, and that they have learned to adapt to the surrounding political and economic environment. For example, many grassroots organizations have used the internet as their main vehicle for recruiting, organizing, and fundraising activities. Russian corporations and foundations are linking with nonpolitical nonstate organizations to address social needs in the immediate community (Alekseeva, 2010). Chebankova (2009) argues that although the public sphere and the ethical functions of civil society are stunted, the associational dimension is "showing some serious signs of successful indepen- 
dent functioning." Benevolenski (2014) reported that the share of Russian NGO funding from national and regional government sources in 2013 was 5 percent, a figure that represents significant growth in Russian state support of nonstate welfare provision.

\section{Examining Nonstate Welfare Provision in the United States}

The story of nonstate welfare provision in the United States mirrors many of the same themes as in the Russian context, such as the primacy of work, deeply held societal values, shifts in the relationship between national and subnational government, major economic shocks, and local preferences. Many of the challenges confronting Russian nonstate welfare provision - inefficiency, duplication, and variability in funding or service accessibility - also are challenges present in the American system. For these reasons, lessons from more mature nonstate welfare provision in the United States may translate to insights relevant to scholars of the Russian welfare state.

The emergence of nonstate welfare provision in the United States reflects a distinctly American view about the causes of poverty and proper ways to intervene or deliver assistance to the needy. Emphasis in American society is placed on the individual work ethic and belief that hard work is the key to upward mobility. These values powerfully shape American societal views of the determinants of poverty. Public opinion historically views poverty as a reflection of individual agency and choices to work, rather than structural factors such as access to opportunity, the availability of jobs, or the adequacy of wages. The primacy of work means that many welfare state functions such as health insurance, retirement benefits, or paid leave are often delivered through private employers, similar in some respects to the role of employers in Russia.

Paralleling entrenched attitudes about poverty and work are powerful societal preferences for how and when to deliver assistance to those in need. Distrust of centralized power limited the role that federal government played in the provision of antipoverty assistance well into the twentieth century. Americans are more comfortable with local welfare provision. Local provision permits communities to tailor aid to local preferences. The American welfare state is also powerfully shaped by the unpopularity of cash assistance programs due to societal beliefs that poverty follows from a lack of a work ethic and concerns that direct cash assistance would provide encouragement not to work.

Given this context, it should come as no surprise that the American welfare state has evolved to prioritize nonstate welfare provision that targets social service programs at the individual-level causes of poverty and provides limited material assistance. The capacity of the nonstate sector in the United States, however, has grown and evolved over nearly two hundred years. Prominent nonstate actors operating in the United States during the nineteenth and early twentieth centuries were local charitable aid organizations that provided basic material assistance and work relief. Although organizations may have drawn on a mix of local public and private resources, it was common for these organizations to have close ties with religious congregations. These early charitable organizations 
often served those living within the boundaries of a defined community and members of particular racial or ethnic groups (Stern \& Axinn, 2012). Assistance also tended to be modest in generosity and limited in duration.

The Great Depression that began in 1929 led to historic increases in unemployment and poverty in the United States. Not only did the Depression hurt many workers and families, but the persistent downturn exhausted nonstate organizations as well as state and local governments' ability to respond to need. Many nonprofit charitable organizations shuttered their doors, unable to generate resources needed to keep up with demand for assistance. In response to the prolonged economic crisis, the federal government became directly involved in widespread provision of antipoverty assistance for the first time. Key hallmarks of federal intervention during this period were a series of programs designed to provide assistance to the poor and to reinforce expectations that able-bodied adults should work. Passage of the Social Security Act of 1935 led to several federal cash assistance programs for the elderly, blind, and mothers with dependent children. Most able-bodied working-age adults, however, remained ineligible for cash assistance, even though unemployment rates remained high and nearhistoric poverty rates persisted into the early 1940s.

Federal support for antipoverty programs increased dramatically starting in 1965. The "War on Poverty" of the late-1960s created many new public funding streams for social services to provide basic food and material assistance, employment assistance, education and literacy programs, housing assistance, child care, child welfare, care for the disabled or elderly, as well as mental health and substance-abuse services (Allard, 2009; Smith \& Lipsky, 1993). Expansion of public funding for nonstate welfare provision has occurred somewhat piecemeal since the early 1970s, with thousands of social service programs accumulating over time. New and expanded federal funding streams have helped launch many new job training, social service, education, and community renewal programs over the past four decades. Complementing these federal efforts, state and local governments also have developed their own programs or contracts to provide social services to low-income populations since the 1970s (Allard, 2009; Smith \& Lipsky, 1993).

Catalyzed by greater government financing of social service programs, nonstate actors shifted from playing a marginal role to a central and highly formalized role in welfare provision. Salamon (2002) finds the number of nonprofit human service organizations and their total revenues more than doubled between 1977 and 1997. Looking at more recent years, Allard (2009) estimates that the number of nonprofit human service and job training service providers increased by more than 60 percent between 1990 and 2003 and total revenues for those organizations doubled during that time. In addition to public funding that is estimated to exceed $\$ 150$ billion annually (Allard 2009), social service nonprofits also receive about $\$ 42$ billion in support from philanthropy, mostly through private donations from individuals, but also from foundations and corporate philanthropy (Giving USA, 2014).

Data from the MSSSP and RSSSP are useful in highlighting key features of contemporary nonstate welfare provision in the United States. As the top panel 
of Table 1 shows, nine of ten local nonstate service organizations interviewed in these seven study sites are formal nonprofits. Six in ten are secular nonprofit organizations and about one-third are religious nonprofit service organizations. The remaining 7 percent of all nonstate actors are for-profit firms. ${ }^{3}$

Table 1

\section{Characteristics of nonstate service organizations in seven urban and rural sites in the United States}

\begin{tabular}{|c|c|}
\hline Organizational characteristic & $\begin{array}{c}\text { Percentage } \\
\text { of organizations }\end{array}$ \\
\hline \multicolumn{2}{|l|}{ Organizational type: } \\
\hline Secular nonprofit & 61.5 \\
\hline Religious nonprofit & 32.0 \\
\hline For-profit & 6.5 \\
\hline \multicolumn{2}{|l|}{ Services offered: } \\
\hline Emergency food or cash assistance & 56.9 \\
\hline Education assistance for adults & 29.5 \\
\hline Job training, search, and placement & 41.6 \\
\hline Financial planning and savings & 33.6 \\
\hline Outpatient substance abuse and/or mental health & 45.5 \\
\hline Assistance with housing needs & 51.2 \\
\hline \multicolumn{2}{|l|}{ Number of clients served in a typical month: } \\
\hline $1-50$ & 29.7 \\
\hline $51-200$ & 34.8 \\
\hline $201-1000$ & 26.7 \\
\hline $1000+$ & 8.8 \\
\hline \multicolumn{2}{|l|}{ More than 50 percent of clients: } \\
\hline Female & 62.8 \\
\hline Black & 29.2 \\
\hline Hispanic & 21.7 \\
\hline Poor & 75.8 \\
\hline Single-parent households & 46.0 \\
\hline Live within 3 miles of organization & 68.9 \\
\hline $\mathbf{N}$ & 1,287 \\
\hline
\end{tabular}

Note: Reported numbers are column percentages of all nonstate service organizations.

Sources: Multi-City Survey of Social Service Providers (MSSSP) and Rural Survey of Social Service Providers (RSSSP). 
Survey data also reflect how nonstate actors operate in a wide array of service areas. In line with the historic focus of the nonstate sector in the United States, more than half of all nonstate organizations interviewed report providing help with basic needs. Nearly six in ten provide material assistance in the form of emergency food or cash assistance. Slightly more than half of nonstate organizations provide assistance to find affordable housing options or providing temporary assistance to pay rent. Consistent with the American welfare state's emphasis on economic self-sufficiency, 29.5 percent of nonstate actors offer adult education services. About four in ten nonstate organizations offer assistance with job training, search, or placement. Many nonstate actors, however, provide highly professionalized services such as outpatient substance- abuse and mental health care (45.5 percent).

These survey data also provide a sense of the capacity and client-focus of nonstate service organizations. In the middle panels of Table 1, we present monthly caseload size across these urban and rural social service organizations. While about one-third are small in size and serve 50 persons or less per month, more than one-third of nonstate organizations serve at least 200 persons per month and almost ten percent maintain caseloads of over 1,000 individuals monthly. All total, these 1,287 nonstate organizations of various sizes and missions reach more than 500,000 individuals in a given month (not shown in Table 1 ). Even a rough extrapolation of these figures to the tens of thousands of municipalities and rural communities in the United States demonstrates the degree in which nonstate actors engage low-income and vulnerable populations.

What do we know about the millions of clients served by nonstate organizations? The bottom panel of Table 1 reports basic demographic characteristics of client caseloads. Social service programs often focus on delivering help to women, often with dependent children. The vast majority of nonstate efforts also appear to be targeted at households with income below the federal poverty line. Reflecting the disproportionately high poverty rates among race and ethnic minorities in the US, we see that sizeable percentages of nonstate organizations serve caseloads that are majority black or Hispanic. Finally, we get a feel for the localness of social service provision by considering that seven in ten nonstate service actors reach populations that live within three miles of their physical office location.

The capacity to serve millions of needy Americans did not emerge overnight. Much of the capacity we take for granted today in the United States evolved slowly in response to different policies. Table 2 examines the founding year of nonstate organizations and underscores the steady emergence of the sector over the last fifty years. One-third of nonstate organizations in operation at the time of the surveys were established between 1965 and 1980, a fifteen-year period following declaration of the War on Poverty. Nevertheless, more than four in ten organizations (42.8 percent) were founded since 1980. While War on Poverty-era federal funding to a variety of antipoverty social service programs kick-started growth of nonstate activity in the United States, several decades of increased program funding and increasingly reliable funding were needed before the nonstate sector matured and developed current capacity. 
Table 2

\section{Establishment of nonstate social service organizations in the seven study sites}

\begin{tabular}{|c|c|c|c|c|c|c|}
\hline \multirow{2}{*}{$\begin{array}{l}\text { Organizational } \\
\text { characteristic }\end{array}$} & \multicolumn{5}{|c|}{ Year nonstate organization founded } & \multirow{2}{*}{$\begin{array}{c}\text { Mean } \\
\text { (standard } \\
\text { deviation) } \\
\text { founding year }\end{array}$} \\
\hline & $\begin{array}{l}\text { Before } \\
1900\end{array}$ & 1900-29 & $1930-64$ & 1965-79 & $\begin{array}{c}1980 \\
\text { or after }\end{array}$ & \\
\hline All nonstate organizations & 8.5 & 7.2 & 11.0 & 30.5 & 42.8 & $1964(37.3)$ \\
\hline \multicolumn{7}{|l|}{ Organizational type: } \\
\hline Secular nonprofit & 3.3 & 6.4 & 11.4 & 39.4 & 39.5 & $1970^{\mathrm{ab}}(26.8)$ \\
\hline Religious nonprofit & 20.5 & 10.0 & 11.4 & 17.0 & 41.1 & $1949^{\mathrm{bc}}(50.3)$ \\
\hline For-profit & 0.0 & 1.4 & 2.9 & 8.6 & 87.1 & $1987^{\mathrm{ac}}(13.4)$ \\
\hline \multicolumn{7}{|l|}{ Services offered: } \\
\hline $\begin{array}{l}\text { Emergency food or cash } \\
\text { assistance }\end{array}$ & 12.6 & 8.8 & 12.3 & 27.4 & 39.0 & $1958(42.2)$ \\
\hline $\begin{array}{l}\text { Education assistance for } \\
\text { adults }\end{array}$ & 8.7 & 8.4 & 9.8 & 32.0 & 41.2 & $1964(36.6)$ \\
\hline $\begin{array}{l}\text { Job training, search, and } \\
\text { placement }\end{array}$ & 6.0 & 8.7 & 10.5 & 35.0 & 39.8 & $1965(33.5)$ \\
\hline $\begin{array}{l}\text { Financial planning and } \\
\text { savings }\end{array}$ & 9.4 & 7.0 & 11.4 & 34.0 & 38.2 & $1963(36.6)$ \\
\hline $\begin{array}{l}\text { Outpatient substance } \\
\text { abuse and/or mental } \\
\text { health }\end{array}$ & 6.4 & 6.7 & 12.9 & 34.2 & 39.8 & $1967(32.8)$ \\
\hline $\begin{array}{l}\text { Assistance with housing } \\
\text { needs }\end{array}$ & 11.9 & 9.4 & 11.2 & 33.5 & 34.0 & $1958(41.6)$ \\
\hline \multicolumn{7}{|l|}{ Annual budget: } \\
\hline More than $\$ 1$ million & 8.6 & 9.9 & 14.4 & 41.8 & 25.3 & $1959^{\mathrm{ab}}(35.1)$ \\
\hline$\$ 1$ million $-\$ 200,000$ & 8.3 & 6.8 & 8.0 & 28.6 & 48.4 & $1967^{\mathrm{ac}}(34.9)$ \\
\hline$\$ 200,000-\$ 50,000$ & 5.3 & 4.2 & 5.8 & 19.6 & 65.1 & $1975^{\mathrm{bc}}(33.3)$ \\
\hline Less than $\$ 50,000$ & 9.9 & 3.8 & 11.5 & 16.8 & 58.0 & $1967(45.2)$ \\
\hline
\end{tabular}

Note: Reported numbers are row percentages.

Sources: MSSSP and RSSSP.

Other important points about the capacity of the nonstate sector emerge in Table 2. First, the historic role of religious nonprofit organizations is clear. The average founding date for religious nonprofits in these seven communities was more than 20 years earlier than secular nonprofits (1949 versus 1970, respectively). Indicative of the trend toward market-based privatization of social service provision in the past three decades (see Smith, 2012), 87 percent of for-profit providers interviewed in these seven sites were established after 1980, with an average founding date of 1987 . Finally, we see the relationship between founding date and size. Nonstate organizations with operating budgets over $\$ 1$ million annually 
were founded much earlier on average than organizations with smaller budgets (1959 versus 1975). Again, capacity in the nonstate sector does not emerge overnight, but evolves and emerges as organizations grow, struggle, and change.

Even though nonstate organizations in the United States have formal independence and autonomy from public agencies, the mutually beneficial and collaborative nature of state-nonstate relationships in social services remains one of its most important features. The private nonprofit sector, in effect, strengthens the public safety net without creating large government bureaucracies to deliver services at the street level.

To highlight the many interdependencies that exist, Table 3 considers the frequency with which nonstate actors receive public funds, develop program-related partnerships with public agencies, and communicate with representatives of government. We find evidence of the government networks in which nonstate actors are embedded. For example, nearly all secular nonprofits, 83.7 percent, receive some public support for their programming. Most nonstate organizations receive public funds from multiple government agencies at the federal, state, and local level - often not just one single source. As a result, public support of nonstate social service provision is a highly fragmented endeavor, which forces organizations to navigate the complexities of multiple applications, reporting systems, and evaluation requirements (Allard, 2009; Allard \& Smith, 2014).

It is also important to assess the degree to which government funds support the work of nonstate actors. Thus, respondents estimated the share of their total budget composed by all public sources. Of secular nonstate organizations receiving public funds, more than half (58.7 percent) are dependent on government funds for at least 50 percent of their operating budget. In fact, 36.5 percent of secular nonprofits receiving government funds are dependent on public funds for more than three-quarters of their total annual budget (not shown in Table 3). A much smaller percentage of religious nonprofit and for-profit organizations are reliant on these public funds, when compared to secular organizations.

Table 3

Government funding and engagement with public actors

\begin{tabular}{|c|c|c|c|}
\hline \multirow[b]{2}{*}{ Organizational characteristic } & \multicolumn{3}{|c|}{ Percentage of organizations } \\
\hline & $\begin{array}{c}\text { Secular } \\
\text { nonprofit }\end{array}$ & $\begin{array}{l}\text { Religious } \\
\text { nonprofit }\end{array}$ & For-profit \\
\hline Received government grants or contracts & $83.7^{\mathrm{ab}}$ & $46.7^{\mathrm{a}}$ & $35.8^{\mathrm{b}}$ \\
\hline $\begin{array}{l}\text { More than } 50 \text { percent of revenues from government grants } \\
\text { or contracts }\end{array}$ & $58.7^{\mathrm{a}}$ & $26.9^{\mathrm{a}}$ & 46.4 \\
\hline Serve residents of public housing developments or programs & 87.6 & 82.4 & 77.8 \\
\hline Serve welfare program participants & $87.1^{\mathrm{ab}}$ & $78.9^{\mathrm{a}}$ & $72.8^{\mathrm{b}}$ \\
\hline \multicolumn{4}{|c|}{ Establish contracts or arrangements to deliver services in partnership with ... } \\
\hline public housing authority & $40.7^{\mathrm{ab}}$ & $26.3^{\mathrm{a}}$ & $23.6^{\mathrm{b}}$ \\
\hline welfare-to-work office & $36.9^{\mathrm{ab}}$ & $16.8^{\mathrm{a}}$ & $14.5^{\mathrm{b}}$ \\
\hline
\end{tabular}




\begin{tabular}{|c|c|c|c|}
\hline \multicolumn{5}{|l|}{ Receive referrals from $\ldots$} \\
\hline public housing authority & $27.3^{\mathrm{ab}}$ & $15.9^{\mathrm{a}}$ & $9.1^{\mathrm{b}}$ \\
\hline welfare-to-work office & $31.2^{\mathrm{ab}}$ & $24.1^{\mathrm{c}}$ & $12.0^{\mathrm{bc}}$ \\
\hline Frequent communication with $\ldots$ & $43.0^{\mathrm{ab}}$ & $26.6^{\mathrm{a}}$ & $21.0^{\mathrm{b}}$ \\
\hline elected representatives to local government & $49.0^{\mathrm{ab}}$ & $23.2^{\mathrm{a}}$ & $21.0^{\mathrm{b}}$ \\
\hline administrators from local or state agencies &
\end{tabular}

Notes: Public housing questions only asked in MSSSP. Reported numbers are column percentages. a,b,c - Each letter represents percent differences within a row that are statistically distinct from zero at the .10 level or below.

Sources: MSSSP and RSSSP.

The middle panels of Table 3 examine the frequency with which nonstate actors might engage with clients of public programs or with the agencies that administer those public programs. In particular, we examine connections to two of the most prominent public assistance programs in the United States: subsidized or public housing assistance and welfare cash assistance to single-parent households through the TANF (Temporary Assistance for Needy Families) program. Each of these programs provides assistance to millions of Americans each year and administration of these programs takes on a highly localized contour, with local offices being responsible for the administration of benefits or assistance (McConnell, Burwick, Perez-Johnson, \& Winston, 2003; Welfare Reform, June 2002). We see that the vast majority of nonstate actors - secular, religious, or for-profit engage clients that also are receiving assistance from public programs. For example, 87.1 percent of secular nonprofits report serving TANF clients, as do 78.9 percent and 72.8 percent of religious nonprofits and for-profits, respectively.

The assistance provided by nonstate actors may fill in gaps not covered by these programs in an informal manner. Or, there may be more formal relationships in place between public and nonstate organizations, where clients are referred to nonstate actors for specific contracted or reimbursed services. The third panel in Table 3 demonstrates the frequency of more formal relationships. Roughly forty percent of secular nonprofits have formal contracting relationships with public housing or welfare offices to deliver services. Smaller, but nontrivial, percentages of religious and for-profit organizations have similar arrangements. Similarly, we see about one-quarter to one-third of secular nonprofits receiving referrals formally from public housing and welfare agencies, compared to approximately less than one in six religious or for-profit organizations. Such patterns of formal engagement logically follow from the closer financial relationships that secular nonprofits maintain with government agencies.

We also see that nonstate actors engage public actors in a number of other ways. The bottom panel of Table 3, for instance, shows that almost one-half of secular nonprofits report frequent communications with local elected officials, or administrative agency staff. Although less common among religious and for-profit service organizations, we see that many report frequent interaction with local elected officials and administrative offices. 
Even though the emergence of the nonstate service sector in the United States was highly dependent upon expansion of federal and state safety net expenditures in the last fifty years, nonstate organizations today maintain complex revenue portfolios that draw upon many sources of support. Table 4 reflects the share of organizations receiving one or more of the following sources of revenue: grants from nonprofit organizations or foundations; private giving from individuals; earned commercial revenue from nongovernmental sources. As is the case with government funding, responses here combine multiple sources of support from a given type. For example, an organization may receive several nonprofit or foundation grants, but responses reflect all nonprofit and foundation funding in the aggregate. Several important findings emerge. First, most organizations draw upon several nongovernmental sources of funding. Roughly two-thirds of secular and religious nonprofits report receiving nonprofit and foundation support. Similarly, most secular and religious nonprofits receive at least some funding through private individual gifts. Earned revenue, most commonly from fees for services or insurance reimbursements, also are common sources of nongovernmental revenue.

Table 4

Nongovernmental funding

\begin{tabular}{|l|c|c|c|}
\hline \multicolumn{1}{|c|}{ Organizational characteristic } & \multicolumn{2}{c|}{ Percentage of organizations } \\
\hline Received grants from nonprofits or foundations & $\begin{array}{c}\text { Secular } \\
\text { nonprofit }\end{array}$ & $\begin{array}{c}\text { Religious } \\
\text { nonprofit }\end{array}$ & For-profit \\
\hline $\begin{array}{l}\text { More than 50 percent of revenues from nonprofits or } \\
\text { foundations }\end{array}$ & $68.0^{\mathrm{a}}$ & $62.2^{\mathrm{b}}$ & $12.3^{\mathrm{ab}}$ \\
\hline Received grants from private giving & $67.5^{\mathrm{ab}}$ & $91.4^{\mathrm{ac}}$ & $8.6^{\mathrm{a}}$ \\
\hline More than 50 percent of revenues from private giving & $5.9^{\mathrm{a}}$ & $37.0^{\mathrm{ab}}$ & $0.6^{\mathrm{bc}}$ \\
\hline Received earned revenue & $34.3^{\mathrm{ab}}$ & $27.9^{\mathrm{ac}}$ & $64.2^{\mathrm{bc}}$ \\
\hline More than 50 percent of revenues from earned revenue & $15.7^{\mathrm{a}}$ & $22.1^{\mathrm{b}}$ & $60.4^{\mathrm{ab}}$ \\
\hline
\end{tabular}

Notes: Reported numbers are column percentages. a,b,c - Each letter represents percent differences within a row that are statistically distinct from zero at the .10 level or below.

Sources: MSSSP and RSSSP.

Organizations that draw on multiple sources of support will be better able to weather tough economic times; dependency on any one source of support may create vulnerabilities. To this point, Table 4 examines the extent to which nonstate organizations in these seven study sites are reliant on a given nongovernmental revenue source for more than 50 percent of their operating budget. Even though most nonprofit organizations actors draw on funding from foundations and individual private giving, only a small fraction of those nonprofit organizations are dependent on those funds. Few for-profit organizations receive charitable gifts or grants, instead relying more heavily upon 
earned revenue for services to complement whatever public revenue streams they can access

While the interdependence of nonstate social service providers and various levels of government funding facilitates efficiency and flexibility in service provision, it also leaves nonstate organizations and their clients vulnerable. When government policy and funding priorities shift, organizations may lose significant proportions of their revenue. In addition, government policy may not always align with nonstate organizations' mission statements, forcing the organization to choose between funding and changing their mission. During economic downturns, nonstate providers face an increase in demand for services while the government may freeze or decrease funding. Nongovernmental donations often decline as well, leaving organizations with impaired service capacity. Finally, nonstate organizations face uncertain revenue streams due to the nature of both government and foundation grant cycles, requiring grant applications or renewals every one to three years, making long-term planning difficult.

Similar to the revenue sources of nonstate organizations, the geography of nonstate welfare provision in the United States is highly diverse. Social service programs, particularly those delivered through nonstate actors, reflect local needs, public resources, private philanthropy, politics, and entrepreneurs (Allard, 2009). As noted, nonstate actors have great discretion over which programs to deliver and which populations to serve. Provision of assistance also reflects local patterns of inequality and opportunity. Ironically, because local tax revenues and philanthropy are directly related to local wealth and economic growth, the resources available to social service programs for lowincome populations may more closely reflect a community's affluence than a community's level of need (Allard \& Roth, 2010). Social service provision, therefore, reflects a variety of local and non-local conditions that translate into wide local variation in the availability and characteristics of services for lowincome populations.

Place-based variation in the provision of social services also is a function of factors that shape location decisions of nonstate service organizations. Many nonstate providers locate in areas where government grants and contracts are available. Some agencies choose to be closer to concentrations of low-income individuals in order to achieve economies of scale for service delivery. Others may locate to be proximate to potential private donors, clients who generate fee revenue, or partnering service organizations. Religious nonprofit service providers are thought to be more likely to operate in high-poverty neighborhoods than other types of nonstate actors, making them more responsive to the needs of the most disadvantaged communities. Programs that address sensitive needs may choose locations that prioritize protecting anonymity and confidentiality over shorter commutes. Moreover, service providers may be bound to particular neighborhoods due to a lack of adequate facilities in more preferred areas, insufficient funds to relocate, or ownership of property and facilities that limits mobility.

Geographic variation in nonstate provision of social services, while understandable in historical and political context, results in uneven provision of 
services to disadvantaged communities. Other analyses of MSSSP and RSSSP survey data show that high-poverty neighborhoods have lower levels of service accessibility than neighborhoods with lower poverty rates. Controlling for supply of services and potential demand across a variety of social service programs, Allard (2009) finds that high-poverty neighborhoods in Chicago, Los Angeles, and Washington, DC (poverty rate over 20 percent) have about one-third as much access to a variety of social services as low-poverty neighborhoods (poverty rate less than 10 percent). Similarly, examining access in the four rural sites covered by the RSSSP, Allard and Cigna (2008) conclude that rural communities often have several sparsely populated high-poverty areas that are distant from any safety net providers. Neighborhoods with higher poverty rates, however, appear to have greater access to religious nonprofits that integrate faith and religious elements into program administration than the typical neighborhood (Allard, 2009). It is clear that not all neighborhoods have equal or adequate access to services.

\section{Conclusion}

It is important to be cautious in drawing analogies between the American welfare state and Russia or other countries with highly centralized welfare states, but nonstate welfare provision in the United States creates incentives for and constraints upon behavior that are endemic to the enterprise. Consequences of nonstate welfare provision may be particularly salient or pronounced in the American context, but its lessons are relevant to the study of nonstate actors in a wide range of settings.

The benefits of nonstate provision of services are many. Often, nonstate agencies fill gaps in services for underserved populations. Nonstate actors play a critical role in building civic community and strengthening social capital in poor neighborhoods and they often link poor persons to community institutions and public agencies. Nonstate actors strengthen other local institutions and community-based agencies through programmatic partnerships and collaboration. In addition, they promote civic participation in the promotion of philanthropy and volunteerism. Importantly, nonstate organizations often raise public awareness of emerging problems and can respond more quickly and flexibly to local issues than can cumbersome state bureaucracies. Combined, these efforts improve the capacity of communities to care for those in need and promote greater well-being among residents.

Other lessons can inform the Russian context as well. First, financing arrangements of nonstate welfare provision may favor efficiency over concerns about equity, sustainability, and predictability. Short-term grant cycles make long-term planning difficult and may restrict the development of more effective programs. Additionally, the proliferation of government-funded programs has provided incentives for the creation of new organizations. Over time this has translated into more intense competition for increasingly finite public program resources, which has reduced the predictability and reliability of those public program resources. Positively, state-funded programs can limit the dis- 
cretion that nonstate actors have over program eligibility. Generally it is believed that state funding forces nonstate actors to treat clients more equitably and with less flexibility than would be the case for programs that are not reliant on state funding (Smith \& Lipsky, 1993). On the other hand, government funding can entice nonstate actors into service delivery areas that may not fit an organization's original mission, pulling nonstate actors away from their core values and competencies.

Second, the primacy of nonstate provision leads to a welfare state that is more varied geographically than might be anticipated otherwise. Local discretion over nonstate service provision means the welfare state only reaches communities in which nonstate organizations are actively engaged. Such variability appears to disadvantage high-poverty and predominately minority communities the most, exacerbating historic patterns of economic, political, and social inequality.

Third, politically, nonstate welfare provision may occur with little public discussion, debate, or reflection. In the U.S. case, poverty and need are often addressed at the individual rather than the structural level. Is this the level at which Russia wants to address need? As relationships between public funding and private provision develop, most community residents and many program clients may not realize they are being served by a nonstate organization. Moreover, the fragmented institutional structures that emerge from nonstate welfare provision make it difficult to plan for the future or assess impact of current investments. How will local, regional, and national governments collaborate to address these challenges?

Insights from the development and current situation of nonstate social service provision in the United States provoke interesting questions for the Russian context. How can the government encourage nonstate organizations in identifying local needs and meeting them without stifling their innovation with restrictive policy? How can funding be provided in a way that is equitable across geographic locations and across vulnerable populations? Can grant funding mechanisms be designed to ensure long-term sustainability of services while also allowing for flexibility to meet changing needs? In what ways can the expertise of nonstate organizations be harnessed in creating policy? In short, how can the Russian government and nonstate organizations collaborate to create a system of social service provision that avoids the pitfalls and maximizes the benefits described here? Russia faces a unique opportunity to forge its own path of state and nonstate social service provision, taking into account lessons learned in other parts of the world. 


\section{REFERENCES}

1. Alekseeva, O. (2010). Commentary on Jakobson and Sanovich: the challenging landscape of the Russian third sector, Journal of Civil Society, vol. 6, n. 3, pp. 307-311.

2. Allard, S.W. (2009). Out of reach: place, poverty, and the new American welfare state, Yale University Press, New Haven, CT.

3. Allard, S.W. (2008). Place, race, and access to the safety net (In: Colors of poverty, eds. A.C. Lin \& D. Harris). New York: Russell Sage Foundation.

4. Allard, S.W. \& Cigna, J. (2008). Access to social services in rural America: the geography of the safety net in the rural west. RUPRI Rural Poverty Research Center Working Paper \#08-01.

5. Allard, S.W. \& Roth, B. (2010). Suburbs in need: rising suburban poverty and challenges for the safety net. Washington, DC: The Brookings Institution, Metropolitan Policy Program Working Paper.

6. Allard, S.W. \& Smith, S.R. (2014). Unforeseen consequences: Medicaid and the funding of social service organizations. Journal of Health Politics, Policy, and Law, vol. 39, n. 6, pp. 1135-1172.

7. Baker, P \& Hinds, K. (2012). Regulators of the global economy: the IMF, the World Bank, and the WTO. (In: Handbook of International Social Work, eds. L. Healy \& R. Link) New York: Oxford University Press, pp. 311-317.

8. Balachova, T.N., Bonner, B.L. \& Levy, S. (2008). Street children in Russia: Steps to prevention. International Journal of Social Welfare, vol. 18, n. 1, pp. 27-44.

9. Belokurova, E. \& Vorob'ev, D. (2011). Local public participation in contemporary Russia. Russian Politics \& Law, vol. 49, n. 4, pp. 76-84. doi: 10.2753/RUP10611940490408.

10. Benevolenski, V. (2014). Russian tools of government for socially oriented NPOs: in search of cross-sector partnership. Paper presented at the $11^{\text {th }}$ International Conference of the International Society for Third-Sector Research (July), Muenster, Germany.

11. Beznosova, O. \& Sundstrom L. (2009). Western aid and the state-society balance in Novgorod and Khabarovsk. Problems of Post-Communism, vol. 56, n. 6, pp. 21-35.

12. Cavanaugh, C. (2010). Players and pawns: the current controversy with and clampdown on NGOs in Russia. (In: Igniting the power of community: The role of CBOs and NGOs in global public health, ed. P. Gaist). New York: Springer, pp. 361-373.

13. Chebankova, E. (2009). The evolution of Russia's civil society under Vladimir Putin: a cause for concern or grounds for optimism? Perspectives on European Politics and Society, vol. 10, n. 3, pp. 394-415.

14. Civic Chamber of the Russian Federation (2013). Who shall provide social assistance? September 19. Available: http://www.oprf.ru/en/print_data/22728 (accessed: 22 November, 2013). 
15. Cook, L.J. (2007a). Negotiating welfare in postcommunist states. Comparative Politics, vol. 40, n. 1, pp. 41-62. doi: 10.2307/20434063.

16. Cook, L.J. (2007b). Postcommunist welfare states: reform politics in Russia and Eastern Europe. Ithaca, NY: Cornell University Press.

17. Cook, L.J. \& Vinogradova, E. (2006). NGOs and social policy-making in Russia's regions. Problems of Post-Communism, vol. 53, n. 5, pp. 28-41.

18. Crotty, J. (2009). Making a difference? NGOs and civil society development in Russia. Europe - Asia Studies, vol. 61, n. 1, pp. 85-108.

19. Crotty, J., Hall, S.M. \& Ljubownikow, S. (2014). Post-Soviet civil Society development in the Russian Federation: the impact of the NGO law. Europe - Asia Studies, vol. 66, n. 8, pp. 1253-1269.

20. Deacon, B., Hulse, M. \& Stubbs, P. (1997). Global social policy: International organizations and the future of welfare. Thousand Oaks, CA, SAGE.

21. Ellman, M. (1979). Socialist planning. Cambridge: Cambridge University Press.

22. Evans, A.B. (2011). The failure of democratization in Russia: a comparative perspective. Journal of Eurasian Studies, vol. 2, n. 1, pp. 40-51.

23. Evans, A.B. (2006). Civil society in the Soviet Union? (In: Russian civil society: a critical assessment, eds. AB. Evans, Jr., L.A. Henry \& L.M. Sundstrom) Armonk, NY: M.E. Sharpe, pp. 28-54.

24. Ferge, Z. (2001). Welfare and 'ill-fare' systems in Central-Eastern Europe. (In: Globalization and European welfare states, eds. R. Sykes, B. Palier \& P. Prior). New York: Palgrave, pp. 127-152.

25. Field, M. \& Twigg, J. (2000). Introduction. (In: Russia's torn safety nets: health and social welfare during the transition, eds. M. Field \& J. Twigg). New York: St. Martin's Press, pp. 1-10.

26. Frohlich, C. (2012). Civil society and the state intertwined: the case of disability NGOs in Russia. East European Politics, vol. 28, n. 4, pp. 371-389.

27. Giving USA Foundation (2014). Giving USA 2014: the annual report on philanthropy for the year 2013, Written and researched by the Indiana University Lilly Family School of Philanthropy.

28. Henderson, S. (2011). Civil society in Russia: state-society relations in the post-Yeltsin era. Problems of Post-Communism, vol. 58, n. 3, pp. 11-27.

29. Henderson, S. (2002). Selling civil society: Western aid and the nongovernmental organization sector in Russia, Comparative Political Studies, vol. 35, n. 2, pp. 139-167.

30. HSE (2011). Spravitsia li gosudarstvo $v$ odinochku? O roli NKO v reshenii sotsial'nykh problem. Rossiiskie obshchestvennyye organizatsii i reshenie sotsial'nykh problem (Does the state have to cope on its own? On the role of NGOs in solving social problems. Russian social organizations and the solving of social problems). Moscow: Higher School of Economics. 
31. Iarskaia-Smirnova, E.R. (2011). Professional ideologies in Russian social work: challenges from inside and outside. (In: Social work education in countries of the East: issues and challenges, ed. S. Selwyn). Hauppauge, NY, Nova Science Publishers, pp. 425-448.

32. Iarskaia-Smirnova, E.R. \& Romanov, P. (2009). Multiplicity and discontinuity in the Soviet welfare history (1940-1980). (In: Social care under state socialism (1945-1989), ed. S. Hering). Opladen, Germany, \& Farmington Hills, MI: Barbara Budrich Publishers, pp. 213-225.

33. Jakobson, L. \& Sanovich, S. (2010). The changing models of the Russian third sector: import substitution phase. Journal of Civil Society, vol. 6, n.3, pp. 279-300.

34. Johnson, J.E. \& Saarinen, A. (2011). Assessing civil society in Putin's Russia: the plight of women's crisis centers. Communist and Post-Communist Studies, vol. 44, n. 1, pp. 41-52.

35. Kamhi, A. (2006). The Russian NGO law: Potential conflicts with international, national, and foreign legislation. The International Journal for Not-for-Profit Law, vol. 9, n. 1, pp. 23-57.

36. Ledeneva, A.V. (2006). How Russia really works: the informal practices that shaped post-Soviet politics and business. Ithaca, NY: Cornell University Press.

37. Lindenmeyr, A. (1990). The ethos of charity in Imperial Russia. Journal of Social History, vol. 23, n. 4, pp. 679-694.

38. Law number 102766-6: On amendments to certain legislative acts of the Russian Federation in the regulation of the activities of non-profit organizations acting as a foreign agent, July 2012. Available: http://asozd2.duma.gov.ru/main.nsf/\%28SpravkaNew\% 29? OpenAgent\&RN=102766-6\&02 (accessed: 15 January, 2015).

39. Livshin, A. \& Weitz, R. 2006, "Civil society and philanthropy under Putin," The International Journal for Not-for-Profit Law, vol. 8, n. 3, pp. 12-14.

40. Ljubownikow, S. \& Crotty, J. (2014). Civil society in a transitional context: the response of health and educational NGOs to legislative changes in Russia's industrialized regions. Nonprofit and Voluntary Sector Quarterly, vol. 43, n. 4, pp. 759-776.

41. Ljubownikow, S., Crotty, J. \& Rodgers, P.W. (2013). The state and civil society in Post-Soviet Russia: the development of a Russian-style civil society. Progress in Development Studies, vol. 13, n. 2, pp. 153-166.

42. Manning, N. \& Shaw, I. (1998). The transferability of welfare models: a comparison of the Scandinavian and state socialist models in relation to Finland and Estonia. Social Policy and Administration, vol. 32, n. 5, SUPPL.2, pp. 572-590.

43. McConnell, S., Burwick, A., Perez-Johnson, I. \& Winston, P. (2003). Privatization in practice: case studies of contracting for TANF case management. Washington, DC: Mathematica Policy Research Inc.

44. Mishler, W. \& Rose, R. (1997). Trust, distrust and skepticism: popular evaluations of civil and political institutions in post-communist societies. The Journal of Politics, vol. 59, n. 2, pp. 418-451. 
45. Petukhov, V.V. (2008). Civil society and the democracy of participation. Russian Social Science Review, vol. 49, n. 4, pp. 4-13.

46. Public Chamber of the Russian Federation (2010). Report on the state of civil society in the Russian Federation, Public Chamber of the Russian Federation, Moscow.

47. Public Chamber of the Russian Federation (2012). Report on the state of civil society in the Russian Federation for 2012, Public Chamber of the Russian Federation, Moscow.

48. Raeff, M. (1984). Understanding imperial Russia: state and society in the old regime. New York: Columbia University Press.

49. Richter, J. (2009). The ministry of civil society? Problems of Post-Communism, vol. 56, n. 6, pp. 7-20.

50. Rimsky, V. (2008). The active civic involvement of Russia’s citizens. Russian Social Science Review, vol. 49, n. 4, pp. 14-24.

51. Salamon, L.M. (2002). The resilient sector: the state of nonprofit America. (In: The state of nonprofit America, ed. L.M. Salamon). Washington, DC: The Brookings Institution Press.

52. Salmenniemi, S. (2010). Struggling for citizenship: civic participation and the state in Russia. Demokratizatsiya, vol. 18, no. 4, pp. 309-328.

53. Smith, S.R., Borodina, A., Borodin, D. \& Rautio.V. (2009). The logic of the development of civic organizations in modern Russia. POLIS. Politicheskie issledovaniia, n. 1, pp. 158-173.

54. Smith, S.R. (2012). Social services. (In: The state of nonprofit America, 2d ed., ed. L.M. Salamon). Washington, DC: The Brookings Institution Press.

55. Sperling, V. \& Lipsky, M. (1993). Nonprofits for hire, Harvard University Press, Cambridge, MA.

56. Sperling, V. (2006). Women's organizations: institutionalized interest groups or vulnerable dissidents? (In: Russian civil society: a critical assessment, eds. A.B. Evans, L.A. Henry \& L.M. Sundstrom) . M.E. Sharpe, Armonk, NY , pp. 161-177.

57. Standing, G. (1996). Social protection in Central and Eastern Europe: a tale of slipping anchors and torn safety nets. (In: Welfare states in transition: national adaptations in global economies, ed. G. Esping-Andersen). London: Sage Publications, pp. 225-255.

58. Stern, M.J. \& Axinn, J. (2012). Social welfare: a history of the American response to need. Boston: Pearson Education.

59. Sundstrom, L.M. (2006). Funding civil society: foreign assistance and NGO development in Russia. Stanford, CA: Stanford University Press.

60. Titterton, M. (2006). Social policy in a cold climate: health and social welfare in Russia. Social Policy \& Administration, vol. 40, n. 1, pp. 88-103. Available: doi: 10.1111/j.1467-9515.2006.00478.x. 
61. Trygged, S. (2009). Social work with vulnerable families and children in 11 Russian regions. European Journal of Social Work, vol. 12, n. 2, pp. 201-220. Available: doi: 10.1080/13691450802567481.

62. UNICEF 1999, After the fall: The human impact of ten years of transition. Florence: Innocenti Publications, UNICEF International Child Development Center.

63. U.S. Agency for International Development (2005). Europe and Eurasia: NGO sustainability index. Washington, DC: U.S. Agency for International Development.

64. Welfare reform: federal oversight of state and local contracting can be strengthened, June 2002. Washington, DC: United States General Accounting Office.

65. Zimakova, T. (1993). The development of the welfare states in Eastern Europe, 1960-75: golden age or gilded age? PSC Research Report 92-258. Ann Arbor, MI: Population Studies Center.

66. Zimakova, T. (1994). A fragile inheritance: family policy in a changing Eastern Europe, PSC Research Report 94-311. Ann Arbor, MI: Population Studies Center.

\section{NOTES}

1 Data were collected between November 2004 and June 2006. There were 296 nonstate organizations interviewed from the four rural sites and 991 interviewed in the three urban sites. The sampling frame for each survey was generated from lists of formally registered nonprofits, service referral guides, and web searches. Thus, these data do not capture many of the informal nonstate providers that operate in low-income communities.

2 For more information about the Multi-City Survey of Social Service Providers (MSSSP) and the Rural Survey of Social Service Providers (RSSSP), visit http://scottwallard.com.

3 Smith (2012) finds that for-profit service organizations in the United States commonly work with youth, elderly, and disabled adult populations, client populations that were not the focus of the organizations included in the MSSSP and RSSSP. 